\title{
Frequency of benzimidazole resistance in Haemonchus contortus populations isolated from buffalo, goat and sheep herds
}

\author{
Frequência da resistência ao benzimidazol em populaçóes de Haemonchus contortus \\ isoladas de rebanhos de bubalinos, caprinos e ovinos
}

Ronaldo Luiz Nunes ${ }^{1}$; Livia Loiola dos Santos ${ }^{1}$; Eduardo Bastianetto ${ }^{2}$;

Denise Aparecida Andrade de Oliveira ${ }^{1}$; Bruno Santos Alves Figueiredo Brasi ${ }^{3,4}$

\author{
${ }^{1}$ Laboratório de Genética Animal, Departamento de Zootecnia, Escola de Veterinária, Universidade Federal de Minas \\ Gerais - UFMG, Belo Horizonte, MG, Brasil \\ ${ }^{2}$ Laboratório de Parasitologia, Departamento de Medicina Veterinária Preventiva, Escola de Veterinária, Universidade Federal de \\ Minas Gerais - UFMG, Belo Horizonte, MG, Brasil \\ ${ }^{3}$ Myleus Biotechnology research team, Belo Horizonte, MG, Brasil \\ ${ }^{4}$ Embrapa Agroenergia, Brasília, DF, Brasil
}

Received June 12, 2013

Accepted October 28, 2013

\begin{abstract}
Anthelmintic resistance is an increasing problem that threatens livestock production worldwide. Understanding of the genetic basis of benzimidazole resistance recently allowed the development of promising molecular diagnostic tools. In this study, isolates of Haemonchus contortus obtained from goats, sheep and buffaloes raised in Brazil were screened for presence of the polymorphism Phe200Tyr in the $\beta$-tubulin 1 gene, which confers resistance to benzimidazole. The allelic frequency of the mutation conferring resistance ranged from $7 \%$ to $43 \%$, and indicated that resistance to benzimidazole could be found in nematodes isolated from all the ruminant species surveyed. Although significant variation in the frequency of the F200Y mutation was observed between different herds or host species, no significant variation could be found in populations isolated from animals within the same herd. These findings suggest that screening of samples from a few animals has the potential to provide information about the benzimidazole resistance status of the entire herd, which would enable a considerable reduction in the costs of diagnosis for the producer. Molecular diagnosis has practical advantages, since it can guide the choice of anthelmintic drug that will be used, before its application in the herd, thus reducing the economic losses driven by anthelmintic resistance.
\end{abstract}

Keywords: Anthelmintic resistance, benzimidazole drugs, molecular diagnosis, domestic ruminants, genetic polymorphisms.

\section{Resumo}

A resistência aos anti-helmínticos é um problema crescente que ameaça a produção pecuária em todo o mundo. A compreensão da base genética da resistência ao benzimidazol permitiu, recentemente, o desenvolvimento de métodos diagnósticos moleculares promissores. Neste estudo, isolados de Haemonchus contortus obtidos a partir de rebanhos de caprinos, ovinos e bubalinos criados no Brasil foram avaliados quanto à presença do polimorfismo F200Y no gene da $\beta$-tubulina1, o qual confere resistência ao benzimidazol. A frequência alélica da mutação variou de $7 \%$ a $43 \%$, indicando que a resistência ao benzimidazol pode ser encontrada em nematoides isolados a partir de todas as espécies de ruminantes pesquisadas. Embora tenha sido observada variação significativa das frequências de mutação F200Y entre rebanhos/espécies hospedeiros distintos, não foi encontrada variação significativa entre populações isoladas de animais dentro de um mesmo rebanho. Estes achados sugerem que a avaliaçấo de amostras de alguns poucos animais tem o potencial de fornecer informaçôes sobre o nível de resistência ao benzimidazol de todo o rebanho, possibilitando uma redução considerável dos custos de diagnóstico para o produtor. O diagnóstico molecular apresenta vantagens práticas, uma vez que pode guiar a escolha da base anti-helmíntica a ser utilizada antes da sua aplicação no rebanho, reduzindo, portanto, as perdas ocasionadas pela resistência aos fármacos anti-helmínticos.

Palavras-chave: Resistência a anti-helmínticos, benzimidazóis, diagnóstico molecular, ruminantes domésticos, polimorfismo genético.

\footnotetext{
${ }^{*}$ Corresponding author: Bruno dos Santos Alves Figueiredo Brasi

Parque Estaçáo Biológica, Av. W3 Norte (final), CEP 70770-901,

Brasília, DF, Brazil

e-mail: bruno.brasil@embrapa.br
} 


\section{Introduction}

Gastrointestinal parasites of the genus Haemonchus constitute a major cause of economic losses in livestock production in tropical and subtropical areas (AMARANTE, 2011). In Brazil, the species Haemonchus contortus prevails in small ruminants, while Haemonchus placei and Haemonchus similis mainly affect cattle (BRASIL et al., 2012). These nematodes, especially the species $H$. contortus, affect the development of young animals by impairing weight gain and increasing mortality.

Although nematode control was achieved through application of anthelmintics until recent years (AHID et al., 2008; SILVA et al., 2010), the widespread use of these drugs has led to emergence of resistant parasites (KAPLAN, 2004; GETACHEW et al., 2007). Therefore, researchers worldwide have been looking for alternative measures for controlling domestic animal helminthiasis. There is an emerging consensus that efficient control programs are highly dependent on knowledge of the regional particularities coupled with accurate diagnosis of the herd's degree of infection and the environmental contamination by using both clinical and laboratory examinations (EYSKER; PLOEGER, 2000). Furthermore, the efficacy of the anthelmintic chosen for use in the herd should also be proved (WALLER, 1999).

Since anthelmintic resistance has become a problem, a number of tests have been developed for assessing the anthelmintic resistance phenotype or genotype of these parasites. Even though in vivo assays such as the fecal egg count reduction test (FECRT) can easily be applied and do not require an expensive laboratory structure, they have low sensitivity and it usually takes 15 days or more for the results to be presented. The sensitivity of in vitro tests is also relatively poor, since they are considered to allow detection of resistance in isolates only when resistanceconferring alleles comprise at least $25 \%$ of the gene pool (VON SAMSON-HIMMELSTJERNA et al., 2009). Furthermore, these methods depend on coprocultures for parasite genus identification (COLES et al., 2006).

On the other hand, molecular tests based on analysis of resistance-associated target gene polymorphisms, through using PCR, are highly sensitive (SILVESTRE; HUMBERT, 2000), do not require coproculture and can complement traditional diagnostic methods. However, one major drawback relating to development of molecular tests is the current poor knowledge of the genetic mutations associated with resistant phenotypes. Nonetheless, in the case of benzimidazole (BZ) drugs, it is now well established that the resistance in trichostrongylid nematodes is mainly associated with replacement of a phenylalanine (Phe, TTC) by a tyrosine (Tyr, TAC) at position 200 (KWA et al., 1994) of the gene encoding $\beta$-tubulin isotype 1 ( $\beta$-tubulin1). Although less frequent, the mutations F167Y (SILVESTRE; CABARET, 2002) and A198G (GHISI et al., 2007) have also been correlated with $\mathrm{BZ}$ resistance.

The objective of this study was to analyze the frequency of a BZ-resistance associated mutation in field isolates of $H$. contortus obtained from different domestic ruminant species in Brazil. In addition, through evaluations on the levels of intra-herd F200Y mutation frequency variation, the results presented here show that it is possible to infer the degree of contamination of the herd from the results obtained from a small group of animals, thereby creating an opportunity for reducing the costs of resistance diagnosis in the field.

\section{Materials and Methods}

Thirty feces samples were obtained directly from the rectum of animals in each of the three herds of different domestic ruminant species analyzed (total: 90 samples). Buffalo samples (Bubalus bubalis) were collected at the farm MG2 (19 41' S; 46 $\left.10^{\prime} \mathrm{W}\right)$, from male Murrah and hybrid buffaloes of ages ranging from 12 to 15 months. Goat samples (Capra hircus) were collected at the farm MG1 ( $19^{\circ} 37^{\prime} \mathrm{S}$; $44^{\circ} 26^{\prime} \mathrm{W}$ ), from male Crioula goats of approximately 10 months of age. Sheep samples (Ovis aries) were collected at the farm SP1 (20 49' S; $\left.49^{\circ} 22^{\prime} \mathrm{W}\right)$, from male and female Santa Inês sheep of approximately 10 months of age. The fecal samples were collected once from each herd between November 2010 and April 2011 and the eggs per gram of feces (EPG) count was determined using the modified McMaster technique (GORDON; WHITLOCK, 1939; UENO; GONÇALVES, 1998). This study was approved by the Ethics Committee of the Federal University of Minas Gerais, Brazil, and followed the legal requirements set by the Genetic Heritage Management Council (CGEN) of the Brazilian Ministry of the Environment. Written consent was provided by the farmers whose farms were used to collect the samples.

Extensive and traditional methods of farming were practiced on all farms. Trading of live animals among farms was conducted at all these farms, but no records of direct trades among these farms were kept. Parasite control through using BZ-class drugs (albendazole) has been routinely performed at SP1 over the last 5 years, among animals that were scored and selected by means of the FAMACHA ${ }^{\circledR}$ method. On the other hand, at MG1 and MG2, BZ drugs have not been used since the establishment of the herds, more than 5 years ago. Treatments using ivermectin have also been performed on all these farms for the last 5 years, in accordance with the animal's age and EPG count and any appearance of clinical signs of infection.

Molecular identification at the species level was performed based on sequences of the second internal transcribed spacer 2 (ITS-2) of rDNA (STEVENSON et al., 1995). Genomic DNA was extracted from single eggs, using a method adapted from Silvestre and Humbert (2000). Representative DNA samples from ten eggs per farm were amplified and sequenced (total: 30 eggs). Briefly, the nuclear ITS-2 rDNA region was amplified using the primers NC1F (5'-ACGTCTGGTTCAGGGTTGTT-3') and NC2R (5'-TTAGTTTCTTTTCCTCCGCT-3') (STEVENSON et al., 1995). A $25 \mu \mathrm{L}$ PCR was performed with $15 \mu \mathrm{L}$ of ultrapure water, $5 \mu \mathrm{L}$ of GoTaq, $5 \mathrm{ml}$ of PCR buffer $\left(2.5 \mathrm{mM} \mathrm{MgCl}_{2}\right)$ (Promega, USA), $0.25 \mu \mathrm{L}$ of each primer $(10 \mu \mathrm{M}), 2.5 \mu \mathrm{L}$ of each dNTP $(1 \mathrm{mM}), 0.25 \mu \mathrm{L}$ of GoTaq DNA polymerase (Promega) $(5 \mathrm{U} / \mu \mathrm{L})$ and $3.0 \mu \mathrm{L}$ of DNA template $(50-100 \mathrm{ng} / \mu \mathrm{L})$. The PCR conditions, in an automated thermocycler (Veriti Life Technologies, USA), were the following: initial denaturation at $94^{\circ} \mathrm{C}$ for $2 \mathrm{~min}$ followed by 35 cycles of denaturation at $94^{\circ} \mathrm{C}$ 
for $30 \mathrm{~s}$, annealing at $55^{\circ} \mathrm{C}$ for $30 \mathrm{~s}$ and extension at $72{ }^{\circ} \mathrm{C}$ for $1 \mathrm{~min}$, with a final elongation step at $72^{\circ} \mathrm{C}$ for $10 \mathrm{~min}$. The PCR products $(1-2 \mathrm{ml})$ were viewed on agarose gel and were selected for direct sequencing. The sequences were determined bi-directionally using the BigDye Terminator v3.1 cycle sequencing kit (Applied Biosystems, Inc., Foster City, California, USA), following the manufacturer's protocol, in an ABI Prism 310 genetic analyzer.

Allele Specific PCR (AS-PCR): Genomic DNA was extracted from single Haemonchus sp. eggs from all the infected animals ( 5 goats, 6 sheep and 2 buffaloes), using an adaptation of the protocol described for larvae in Silvestre and Humbert (2000). Genotyping of the polymorphism TTC/TAC at position 200 of isotype 1 of the $\beta$-tubulin gene was performed on at least 10 specimens from each host, by means of a Haemonchus sp. specific reaction of AS-PCR, as described by Niciura et al. (2012). Plasmids containing cloned $\beta$-tubulin 1 alleles bearing either the TTC200 (S allele) or the TAC200 (R allele) SNPs previously obtained by Brasil et al. (2012) were included as controls. Chi-square tests were conducted to compare allelic frequencies, using the SAEG 9.1 software (2007).

\section{Results and Discussion}

The total prevalence of helminth infection ranged from $6.6 \%$ in the buffalo herd (MG2) to $16.6 \%$ in the goat herd (MG1) and $20 \%$ in the sheep herd (SP1) (Table 1). The average EPG counts were also highest in the sheep herd $(7,750)$, while the buffalo herd (200) and goat herd (1,000) presented lower counts. This was not unexpected, given the different susceptibilities of these ruminant species to nematode infections (KAPLAN, 2004). Sequencing of the ITS-2 region is an efficient tool for identifying nematode species (STEVENSON et al., 1995). Thus, sequences of the ITS-2 region were obtained from the DNA extracted from 30 representative specimens: 10 eggs were selected from a pool from each of the three herd isolates. All the samples analyzed were identified as $H$. contortus $(100 \%$ similarity to GenBank sequences JQ342248 or JQ342249). These results reveal that $H$. contortus is probably the major nematode species infecting the ruminants tested. This finding is compatible with the helminthic fauna described by Borges et al. (2001), Veríssimo et al. (2012) and Brasil et al. (2012). Since only a fraction of the eggs sampled were identified by means of sequencing $(\mathrm{n}=30)$, it is also not surprising that $H$. contortus appears to be a major species, given its high prolificacy and consequently its greater relative abundance of eggs, in comparison with other helminths.

AS-PCR-based genotyping using Haemonchus sp. specific primers (NICIURA et al., 2012) was performed and presented positive amplification for 182 out of 203 eggs tested, which was in accordance with the high prevalence of $H$. contortus found in the samples analyzed. The results presented in Table 2 show that the frequency of alleles bearing the TAC200 polymorphism in the $\beta$-tubulin isotype 1 gene ( $\mathrm{R}$ alleles) was lower in the herds of goats (9\%) and buffalo (7\%), than in the sheep herd (43\%). Figure 1 shows a representative result from AS-PCR, including the appropriate controls used for validation of the method. High levels of resistance to BZ have recently been reported in several herds in Brazil (CRUZ et al., 2010; NICIURA et al., 2012; VERÍSSIMO et al., 2012). Furthermore, the higher frequency of ATH treatment in the SP1 herd (4 or more treatments/year) might also explain the higher frequency of the $\mathrm{R}$ alleles obtained (Table 2). It is also important to highlight that resistant alleles could be found in nematodes isolated from all the three domestic ruminant species analyzed, even in the herds that were not under BZ selective pressure, i.e. MG1 and MG2. This might be a consequence of the high gene flow and low genetic structure frequently found in trichostrongylid populations, which is caused by frequent animal movements between farms, as well as by sharing of pasture areas and facilities by different ruminant species (BLOUIN et al., 1995; SILVESTRE et al., 2009; BRASIL et al., 2012).

Recent studies have focused on the distribution of the genetic variability and population structure of trichostrongylids, based on neutral markers (BLOUIN et al., 1995; BRAISHER et al., 2004; CERUTTI et al., 2010; ARCHIE; EZENWA, 2011) and genes under ATH selective pressure (SILVESTRE et al., 2009; BRASIL et al., 2012). However, data on the distribution and variation of anthelmintic resistance-conferring polymorphisms

Table 1. Helminthic infection levels according to EPG counts.

\begin{tabular}{|c|c|c|c|c|c|}
\hline $\begin{array}{l}\text { Farm identification } \\
\text { (latitude/longitude) }\end{array}$ & Host species & $\begin{array}{l}\text { Number of infected } \\
\text { animals (frequency) }\end{array}$ & $\begin{array}{c}\text { Infected animal } \\
\text { identification }\end{array}$ & EPG & $\begin{array}{c}\text { Number of specimens } \\
\text { genotyped }\end{array}$ \\
\hline \multirow[t]{5}{*}{ MG1 (19 $\left.37^{\circ} \mathrm{S} / 44^{\circ} 26^{\prime} \mathrm{W}\right)$} & Goat & $5(16.6 \%)$ & CV1 & 6,700 & 20 \\
\hline & & & CV2 & 1,000 & 12 \\
\hline & & & CV3 & 1,500 & 13 \\
\hline & & & CV4 & 4,100 & 10 \\
\hline & & & CV5 & 1,000 & 10 \\
\hline \multirow[t]{6}{*}{ SP1 (20 49’ S / 49²2’ W) } & Sheep & $6(20 \%)$ & OV1 & 33,000 & 10 \\
\hline & & & OV2 & 400 & 10 \\
\hline & & & OV3 & 800 & 10 \\
\hline & & & OV4 & 1,300 & 15 \\
\hline & & & OV5 & 10,500 & 25 \\
\hline & & & OV6 & 500 & 15 \\
\hline \multirow[t]{2}{*}{ MG2 $19^{\circ} 41^{\prime} \mathrm{S} / 46^{\circ} 10^{\prime} \mathrm{W}$} & Buffalo & $2(6.6 \%)$ & $\mathrm{BF} 1$ & 200 & 20 \\
\hline & & & BF2 & 1,400 & 12 \\
\hline
\end{tabular}




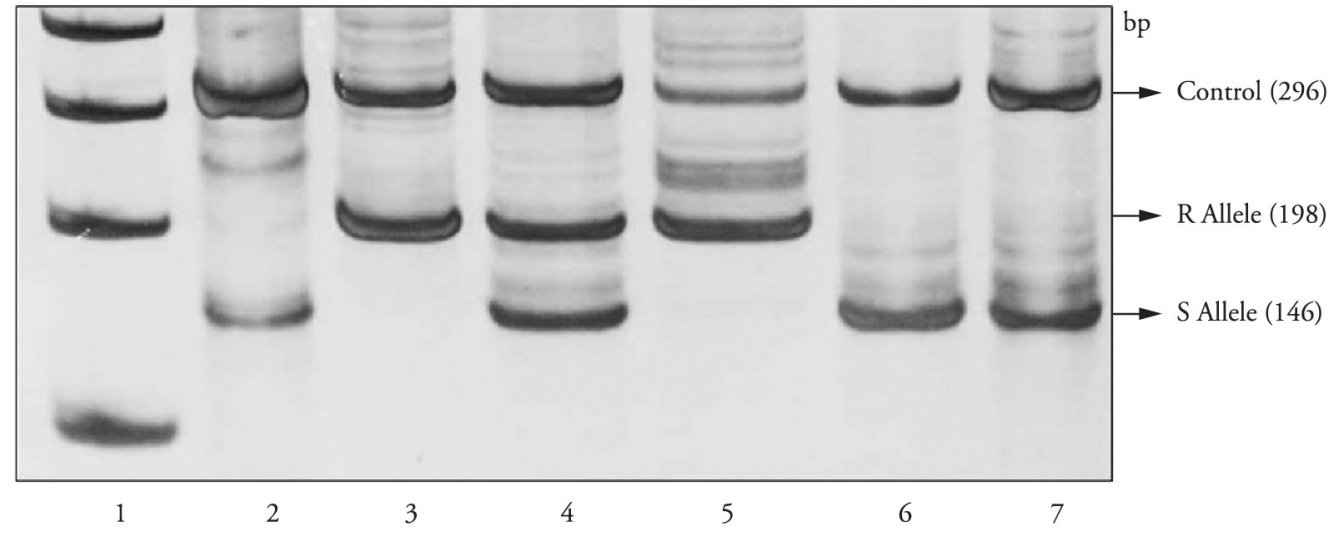

Figure 1. Genotyping of codon 200 of $\beta$-tubulin1 by means of AS-PCR - Representative picture of a silver nitrate-stained native polyacrylamide gel loaded with $5 \mathrm{ml}$ of AS-PCR products and subjected to electrophoresis. Lanes: 1) DNA size marker; 2-4) Plasmids containing the cloned control alleles of $\beta$-tubulin1 bearing either the 200TTC SNP (S allele) or the 200TAC SNP (R allele): (2) SS - susceptible homozygous control; (3) RR - resistant homozygous control; (4) RS - heterozygous control; (5-7) Representative eggs genotyped: (5) RR egg from sheep; (6) SS egg from goat; (7) SS egg from buffalo.

Table 2. Allelic and genotypic frequencies of the F200Y polymorphism of the $\beta$-tubulin 1 gene in the MG1, MG2 and SP1 herds. Chi-square tests were used to evaluate the statistical differences among the herds' allelic frequencies. $\mathrm{f}(\mathrm{R})$ : frequency of the BZ resistance-conferring allele (F200Y); f(S): frequency of the BZ sensitivity-conferring allele; RR: resistant homozygous genotype; RS: heterozygous genotype (phenotypically susceptible); SS: susceptible homozygous genotype.

\begin{tabular}{|c|c|c|c|c|c|c|c|}
\hline Herd/host animal & $\mathbf{f}(\mathbf{R})$ & $f(S)$ & RR (\%) & RS (\%) & SS (\%) & $\chi^{2}$ & $p$ \\
\hline MG1/CV1 & $4(0.10)$ & $36(0.90)$ & $1(5.0)$ & $2(10.0)$ & $17(85.0)$ & - & - \\
\hline MG1/CV2 & $2(0.08)$ & $22(0.92)$ & $0(0.0)$ & $2(16.7)$ & $10(83.3)$ & - & - \\
\hline MG1/CV3 & $2(0.07)$ & $24(0.93)$ & $0(0.0)$ & $2(15.4)$ & $11(84.6)$ & - & - \\
\hline MG1/CV4 & $2(0.10)$ & $18(0.90)$ & $0(0.0)$ & $2(20.0)$ & $8(80.0)$ & - & - \\
\hline MG1/CV5 & $2(0.10)$ & $18(0.90)$ & $0(0.0)$ & $2(20.0)$ & $8(80.0)$ & - & - \\
\hline MG1/total & 0.09 & 0.91 & $1(1.5)$ & $10(15.4)$ & $54(83.1)$ & 0.153 & 0.997 \\
\hline SP1/OV1 & $10(0.50)$ & $10(0.50)$ & $0(0.0)$ & $10(100.0)$ & $0(0.0)$ & - & - \\
\hline SP1/OV2 & $10(0.50)$ & $10(0.50)$ & $1(10.0)$ & $8(80.0)$ & $1(10.0)$ & - & - \\
\hline SP1/OV3 & $9(0.45)$ & $11(0.55)$ & $0(0.0)$ & $9(90.0)$ & $1(10.0)$ & - & - \\
\hline SP1/OV4 & $15(0.50)$ & $15(0.50)$ & $0(0.0)$ & $15(100.0)$ & $0(0.0)$ & - & - \\
\hline SP1/OV5 & $25(0.50)$ & $25(0.50)$ & $1(4.0)$ & $23(92.0)$ & $1(4.0)$ & - & - \\
\hline SP1/OV6 & $13(0.43)$ & $17(0.57)$ & $0(0.0)$ & $13(86.7)$ & $2(13.3)$ & - & - \\
\hline SP1/total & 0.43 & 0.57 & $2(2.3)$ & 78 (91.8) & $5(5.9)$ & 0.522 & 0.991 \\
\hline MG2/BF1 & $3(0.10)$ & $27(0.9)$ & $0(0.0)$ & $3(20.0)$ & $12(80.0)$ & - & - \\
\hline MG2/BF2 & $1(0.04)$ & $23(0.96)$ & $0(0.0)$ & $1(0.08)$ & $11(0.92)$ & - & - \\
\hline MG2/total & 0.07 & 0.93 & $0(0)$ & $4(14.8)$ & $23(85.2)$ & 0.661 & 0.461 \\
\hline
\end{tabular}

among individual animal nematode communities within herds are still scarce, especially with regard to important domestic ruminant species such as buffaloes. The results based on chi-square tests shown in Table 2 demonstrate that there is no significant variation in the frequency of the F200Y SNP among animals within the same herd, irrespective of the host species analyzed. Thus, it should be possible to estimate the frequency of resistance to benzimidazole for the entire herd by sampling only a few individuals. Furthermore, use of molecular techniques for diagnosing resistance presents advantages over the traditional methods, since time-consuming steps such as coproculture are not necessary and it is possible to identify BZ resistance even at low levels (Table 2), directly from DNA extracted from nematode eggs.
Therefore, it is advisable that farmers should monitor the frequencies of any anthelmintic resistance-associated mutations present in the nematode populations that are prevalent in their herds. Von Samson-Himmelstjerna et al. (2009) reported that the critical level indicating phenotypic resistance to BZ drugs (e.g. FECRT $\leq 95 \%$ or egg hatching assays with EC50 $\geq 0.1 \mu \mathrm{g}$ of thiabendazole/ml) corresponded to an allelic frequency $\leq 27.4 \pm 5.3 \%$ for the susceptible allele (not carrying the F200Y mutation), in the $H$. contortus population. This would allow farmers to make rational decisions about changing the class of the drug used, as would be recommended in the case of the SP1 farm. Furthermore, rises in resistance-conferring alleles to unmanageable levels could be avoided, since molecular tests 
can detect resistance before it becomes phenotypically apparent from FECRT on the nematode population. This will be especially useful in cases where anthelmintic resistance is a recessive trait, such as $\mathrm{BZ}$ resistance.

\section{Conclusions}

Screening for nematodes isolated from a few animals has the potential to provide information about anthelmintic resistance that is applicable to the entire herd. It is possible to considerably reduce the time and cost of benzimidazole resistance testing in the field by using the molecular methods presented in this study.

\section{Acknowledgements}

This study was supported by CNPq (INCT 573899/2008-8) and FAPEMIG (INCT APQ-0084/08).

\section{References}

Ahid SMM, Suassuna ACD, Maia MB, Costa VMM, Soares HS. Parasitos gastrointestinais em caprinos e ovinos da Regiáo Oeste do Rio Grande do Norte. Ciênc Anim Bras 2008; 9(1): 212-218.

Amarante AFT. Why is it important to correctly identify Haemonchus species? Rev Bras Parasitol Vet 2011; 20(4): 263-268. http://dx.doi. org/10.1590/S1984-29612011000400002

Archie EA, Ezenwa VO. Population genetic structure and history of a generalist parasite infecting multiple sympatric host species. Int J Parasitol 2011; 41(1): 89-98. http://dx.doi.org/10.1016/j. ijpara.2010.07.014

Blouin MS, Yowell CA, Courtney CH, Dame JB. Host movement and the genetic structure of populations of parasitic nematodes. Genetics 1995; 141(3): 1007-1014.

Braisher TL, Gemmell NJ, Grenfell BT, Amos W. Host isolation and patterns of genetic variability in three populations of Teladorsagia from sheep. Int J Parasitol 2004; 34(10): 1197-1204. http://dx.doi. org/10.1016/j.ijpara.2004.06.005

Brasil BSAF, Nunes RL, Bastianetto E, Drummond MG, Carvalho DC, Leite RC, et al. Genetic diversity patterns of Haemonchus placei and Haemonchus contortus populations isolated from domestic ruminants in Brazil. Int J Parasitol 2012; 42(5): 469-479. http://dx.doi.org/10.1016/j. ijpara.2012.03.003

Borges FA, Silveira DM, Graminha EBN, Castagnoli KC, Soares VE, Nascimento AA, et al. Fauna helmintológica de bovinos da região de Jaboticabal, Estado de São Paulo. Semina: Ciênc Agrárs 2001; 22(1): 45-50.

Cerutti MC, Citterio CV, Bazzocchi, C, Epis S, D’Amelio S, Ferrari N, et al. Genetic variability of Haemonchus contortus (Nematoda: Trichostrongyloidea) in alpine ruminant host species. J Helminthol 2010; 84(3): 276-283. http://dx.doi.org/10.1017/ S0022149X09990587

Coles GC, Jackson F, Pomroy WE, Prichard RK, von SamsonHimmelstjerna G, Silvestre A, et al. The detection of anthelmintic resistance in nematodes of veterinary importance. Vet Parasitol 2006; 136(34): 167-185. http://dx.doi.org/10.1016/j.vetpar.2005.11.019
Cruz DG, Rocha LO, Arruda SS, Palieraqui JGB, Cordeiro RC, Santos Junior E, et al. Anthelmintic efficacy and management practices in sheep farms from the state of Rio de Janeiro, Brazil. Vet Parasitol 2010; 170(34): 340-343. http://dx.doi.org/10.1016/j.vetpar.2010.02.030

Eysker M, Ploeger HW. Value of present diagnostic methods for gastrointestinal nematode infections in ruminants. Parasitology 2000; 120(Supl): 109-119.

Getachew T, Dorchies P, Jacquiet P. Trends and challenges in the effective and sustainable control of Haemonchus contortus infection in sheep. Parasite 2007; 14(1): 3-14. http://dx.doi.org/10.1051/ parasite/2007141003

Ghisi M, Kaminsky R, Mäser P. Phenotyping and genotyping of Haemonchus contortus isolates reveals a new putative candidate mutation for benzimidazole resistance in nematodes. Vet Parasitol 2007; 144(34): 313-320. http://dx.doi.org/10.1016/j.vetpar.2006.10.003

Gordon HM, Whitlock HV. A new technique for counting nematode eggs in sheep faeces. J Council Sci Ind Res 1939; 12: 50-52.

Kaplan RM. Drug resistance in nematodes of veterinary importance: a status report. Trends Parasitol 2004; 20(10): 477-481. http://dx.doi. org/10.1016/j.pt.2004.08.001

Kwa MS, Veenstra JG, Roos MH. Benzimidazole resistance in Haemonchus contortus is correlated with a conserved mutation at amino acid 200 in b-tubulin isotype 1. Mol Biochem Parasitol 1994; 63(2): 299303. http://dx.doi.org/10.1016/0166-6851(94)90066-3

Niciura SC, Veríssimo CJ, Gromboni JG, Rocha MI, De Mello SS, Barbosa CM, et al. F200Y polymorphism in the b-tubulin gene in field isolates of Haemonchus contortus and risk factors of sheep flock management practices related to anthelmintic resistance. Vet Parasitol 2012; 190(3-4): 608-612. http://dx.doi.org/10.1016/j. vetpar.2012.07.016

Sistema para Análises Estatísticas - SAEG. versão 9.1. Viçosa: Fundação Arthur Bernardes; 2007.

Silva MRL, Souza EA, Bonelli EA, Medeiros MO, Silva GF, Queiroz EO. Parasitas gastrointestinais de ovinos criados na regiáo de RondonópolisMT. Rev Biodiv 2010; 9(1): 67-73.

Silvestre A, Cabaret J. Mutation in position 167 of isotype 1 beta-tubulin gene of Trichostrongylid nematodes: role in benzimidazole resistance? Mol Biochem Parasitol 2002; 120(2): 297-300. http://dx.doi.org/10.1016/ S0166-6851(01)00455-8

Silvestre A, Humbert JF. A molecular tool for species identification and benzimidazole resistance diagnosis in larval communities of small ruminant parasites. Exp Parasitol 2000; 95(4): 271-276. http://dx.doi. org/10.1006/expr.2000.4542

Silvestre A, Sauve C, Cortet J, Cabaret J. Contrasting genetic structures of two parasitic nematodes, determined on the basis of neutral microsatellite markers and selected anthelmintic resistance markers. Mol Ecol 2009; 18(24): 5086-5100. http://dx.doi.org/10.1111/j.1365294X.2009.04421.x

Stevenson LA, Chilton NB, Gasser RB. Differentiation of Haemonchus placei from $H$. contortus (Nematoda: Trichostrongylidae) by the ribosomal DNA second internal transcribed spacer. Int J Parasitol 1995; 25(4): 483 488. http://dx.doi.org/10.1016/0020-7519(94)00156-I

Ueno H; Gonçalves PC. Manual para diagnóstico da helmintoses de ruminantes. Tokyo: Japan International Cooperation Agency, 1998. 
Veríssimo CJ, Niciura SCM, Alberti ALL, Rodrigues CFC, Barbosa CMP, Chiebao DP, et al. Multidrug and multispecies resistance in sheep flocks from São Paulo state, Brazil. Vet Parasitol 2012; 187(1-2): 209-216. http://dx.doi.org/10.1016/j.vetpar.2012.01.013

Von Samson-Himmelstjerna G, Walsh TK, Donnan AA, Carrière S, Jackson F, Skuce PJ, et al. Molecular detection of benzimidazole resistance in Haemonchus contortus using real-time PCR and pyrosequencing. Parasitology 2009; 136(3): 349-358. http://dx.doi.org/10.1017/ S003118200800543X

Waller PJ. International approaches to the concept of integrated control of nematode parasites of livestock. Int J Parasitol 1999; 29(1): 155-164. http://dx.doi.org/10.1016/S0020-7519(98)00178-7 